\title{
THE ROLE OF METAPHOR AND METONYMY AS TOOLS OF LEXICAL CREATION: THE CASE OF SPANISH INFORMAL SPEECH ${ }^{* 1}$
}

\author{
Javier Herrero Ruiz**
}

\begin{abstract}
In the Cognitive Linguistics paradigm it is well known that conceptual metaphor and metonymy, among their various functions, are two important tools of lexical creation. Nevertheless, the literature on the topic is almost exclusively concerned with the analysis of well-established and formal varieties of language to the detriment of informal speech. This paper attempts to fill this void by describing some current informal speech expressions in Spanish which may be considered the result of these two cognitive operations; additionally, whenever possible, we offer their English counterparts. We thus explore the way in which these analytic tools play a crucial role in the proper understanding of expressions such as "estoy de bajón" (UNHAPPY IS DOWN), "vas ciego esta noche" (KNOWLEDGE IS VISION), "ya vienen los pitufos" (COLOUR OF UNIFORM FOR POLICEMAN), "esa chica está cañón" (BEING ATTRACTIVE IS HAVING PHYSICAL FORCE), etc. The expressions under consideration have been mainly obtained on the basis of Google searches and from Spanish newspapers.
\end{abstract}

Keywords: Cognitive Linguistics, metaphor, metonymy, lexical creation, Spanish informal speech.

Resumen: En el paradigma de la Lingüística Cognitiva es bien sabido que tanto la metáfora como la metonimia son, entre sus varias funciones, importantes mecanismos de creación léxica. Sin embargo, los estudios llevados a cabo sobre el tema se centran esencialmente en el análisis de variedades lingüísticas formales y bien asentadas, relegando a un segundo plano el lenguaje informal. Con el fin de llenar este vacío, el presente artículo analiza algunas expresiones de la lengua española informal que pueden ser consideradas fruto de estas operaciones mentales; además, siempre que sea factible, incluimos los equivalentes en inglés. Para ello, exploraremos cómo estas herramientas analíticas juegan un papel crucial en la correcta comprensión de varias expresiones como "estoy de bajón" (UNHAPPY IS DOWN), "vas ciego esta noche" (KNOWLEDGE IS VISION), "ya vienen los pitufos" (COLOUR OF UNIFORM FOR POLICEMAN), "esa chica está cañón" (BEING ATTRACTIVE IS HAVING PHYSICAL FORCE), etc. Los ejemplos han sido extraídos de diversos periódicos españoles y de búsquedas en Google.

Palabras clave: Lingüística Cognitiva, metáfora, metonimia, creación léxica, lengua española informal.

Fecha de recepción: abril 2005

Fecha de aceptación y versión final: mayo 2005

*** Becario F.P.I., Departamento de Filologías Modernas, Universidad de La Rioja; $\square$ javier.herrero@dfm.unirioja.es.

${ }^{1}$ Part of a talk delivered at AESLA Annual Conference, 2005. Financial support for this research has been provided by the DGI, Spanish Ministry of Education and Science, grant no. HUM 2004-05947-C02-01/ FILO. The research has been co-financed through FEDER funds. 


\section{INTRODUCTION}

This paper attempts to provide additional evidence in support of the by now well accepted thesis that metaphor and metonymy are crucial mechanisms of lexical creation (cf. Dirven, 1999; Kövecses \& Radden, 1998; Koch, 2001; Frath, 2003, 2005). The corpus of analysis contains 98 Spanish informal speech expressions (selected from Spanish magazines and newspapers, and some Google searches) that can be regarded as the result of these two cognitive operations. Also, whenever possible, we offer their English renderings.

We first outline the basics of metaphor theory and determine how it is to be distinguished form metonymy. We then turn our attention to the analysis of the informal expressions we have selected and of their underlying metaphors and metonymies.

\section{DEFINING METAPHOR AND METONYMY}

It would be impossible to do justice to the impressive amount of work that has been done on metaphor even if we restrict our account to the last three decades. By point of contrast with the Cognitive Linguistics eminently representational approach, the reader may be referred to the various approaches taken within pragmatics and the philosophy of language, such as Davidson (1978), who was one of the first to argue that metaphor is computed directly (i.e. it is not first processed directly and then non-literally), Martinich (1984), who explained its pragmatic value as a flouting (i.e. an ostentatious violation) of one of the maxims of quality from the Cooperative Principle (Grice, 1975), or Searle (1982), who set up a number of principles of metaphorical interpretation based on the speaker's perception of the relationship between so-called vehicle and tenor.

In Cognitive Linguistics, metaphor is regarded as one of several kinds of idealised cognitive model (or ICM). ICMs are conceptual representations that result from the activity of a number of structuring principles, like image-schematic reasoning, argument-predicate relations, and metaphoric and metonymic mappings. Metaphor is described as a mapping or set of correspondences across discrete conceptual domains. Traditionally, cognitive linguists have followed Lakoff \& Johnson (1980: 35-40) and Lakoff \& Turner (1989: 103104) in their initial observations on the differences between metaphor and metonymy. In fact, their characteristics are very different:

(1) In metaphor there are two conceptual domains involved, one being understood in terms of the other, while metonymy only involves one conceptual domain, i.e. the mapping occurs within a single domain and not across domains.

(2) In metaphor, the source domain is mapped onto the target domain, and thus it is mainly used for understanding, e.g. I have control over him (CONTROL IS UP). In contrast, metonymy is mainly used for reference, since we can refer to an entity in a domain by referring to another entity within the same domain, e.g. Wall Street is in crisis (the street stands for the institution).

(3) The relationship between the source and target domains in metaphor is of the "is a" kind; in metonymy there is a "stands for" relationship, since one entity in a domain is taken as standing for another entity in the same domain or for the domain as a whole. 
However, as Ruiz de Mendoza (1997a: 283) has noted, the only essential difference between metaphor and metonymy is related to the domain-internal and domain-external nature of the mapping, since both metaphor and metonymy can be used either referentially or predicatively. In this sense, The pig is waiting for his bill (the pig is the customer) and Wall Street is in crisis (the street stands for the institution) are examples of referential metaphor and metonymy respectively, whereas I have control over him (CONTROL IS UP) and He is a (real) brain ('he is very intelligent') are instances of metaphor and metonymy used predicatively.

The "stands for" relationship is simply the result of the domain-internal nature of metonymic mappings; that is, the false impression that metonymies obligatorily require a "stands for" relationship derives from the fact that metonymies are constructed on the basis of a single conceptual domain, in such a way that one of the domains is part of the other.

Ruiz de Mendoza (1997b: 169-171) also argues for the existence of two basic types of metaphor from the point of view of the nature of the mapping process. Hence, we may find one-correspondence metaphors (there is just one correspondence between the source and target domains; e.g. PEOPLE ARE ANIMALS, in which animal behaviour is mapped onto human behaviour) and many-correspondence metaphors (there are several correspondences between the source and target domains; e.g. LOVE IS A JOURNEY, in which lovers are seen as travellers, the lovers' shared goals are the destination, etc.).


Figure 1. One-correspondence and many-correspondence metaphors

Metonymies, which can be defined as instances of one-correspondence mappings, have been divided into target-in-source (the source domain stands for a target sub-domain) and source-in-target (a source sub-domain stands for a target domain) metonymies (Ruiz de Mendoza, 2000; Ruiz de Mendoza \& Pérez, 2001).
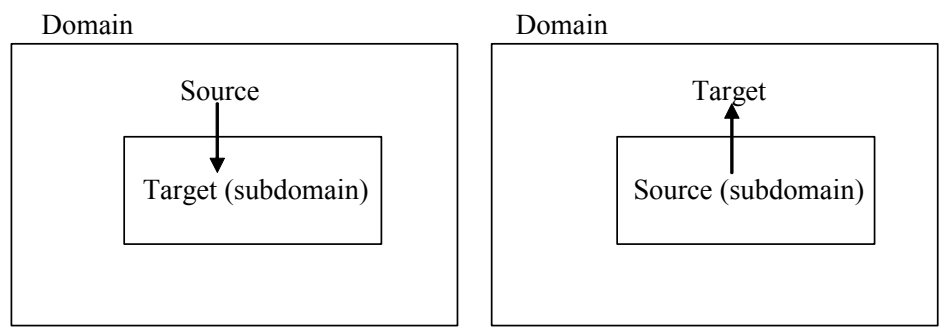

Figure 2. Target-in-source and source-in-target metonymies 
The two aforementioned types of metonymic mapping correlate with the two basic functions of metonymy: first, source-in-target metonymies involve domain expansion (i.e. they provide full access to the main domain, called by Ruiz de Mendoza (2000) matrix domain, by means of one of its subdomains); second, target-in-source metonymies involve domain reduction, which leads to the highlighting of a relevant part of a domain. Domain expansion and domain reduction operations have been given pride of place in later work by Ruiz de Mendoza and his associates (cf. Ruiz de Mendoza \& Santibáñez, 2003; Ruiz de Mendoza \& Peña, 2005; Ruiz de Mendoza, 2005). What is more interesting, the role of these operations has been addressed not only from the representational view, as is common practice in Cognitive Linguistics, but also from the communicative standpoint. The resulting account has wide-ranging implications for the study of the relationship between pragmatics and cognition that we cannot address in detail here. With respect to metaphor, suffice it to mention that many-correspondence metaphorical systems have a greater implicational potential than one-correspondence systems. The greater implicational potential of many-correspondence systems is a function of their more complex nature. When faced with them, hearers have to explore the conceptual domains involved and come up with a (plausible) central interpretation plus a set of associated meaning effects. For example, if I say that I have come to a crossroads in my life, the most central implication will be that I find myself uncertain as to what I have to do next. Other possible implications may be that I have been making satisfactory progress until now but that I may need to explore other progress alternatives, or that I may have to "retrace my steps" (i.e. go back to previous forms of activity directed to achieve my goals) a little bit so as to rethink the extent of my progress. The actual nature of these implications will largely depend on how the hearer can combine his knowledge about me with the conventionalised (conceptual) correspondences of the "journey" metaphor.

One-correspondence systems (e.g. PEOPLE ARE ANIMALS/ PLANTS/ MACHINES) are usually heavy conventionalised and do not require but a little adaptation work in connection to the context in which they are used. They are usually based on one single (highlighted) feature or on a set of related features. Thus, a pig is an immoral, dirty or abusive person; a lion is a brave person; a dragon is a nasty, aggressive lady; a machine is untiring; an oak is strong, and so forth.

Metonymies are very poor from the point of view of their implicational structure; however, they are economical in processing terms, each kind for different reasons. Sourcein-target metonymies provide a point of access to a broader conceptual domain; in so doing, it is up to the hearer to expand the conceptual material supplied by the starting point until a satisfactory development has been reached. This characteristic of source-intarget metonymies makes them amenable to be work on situational cognitive models or scenarios. Thus, in Stand up to what you believe is true, the idea of 'standing up' seems to invoke the more complex scene of a person standing to his feet in order to defend his views in a more energetic and emphatic way. Target-in-source metonymies, on the other hand, work by placing in focus a non-central subdomain within a broader matrix domain. This operation is particularly useful when the speaker is unable (or simply believes it is totally unnecessary) to give a fully-fledged description of a given entity. For example, in CocaCola has changed its marketing policy, 'Coca Cola' is used to stand for any relevant 
person or group of people in charge of marketing the product. The operation is also economical since the speaker may avoid providing long and usually awkward expressions describing the intended referent.

In Ruiz de Mendoza's latest work, metaphoric and metonymic operations are but part of a more complex set of cognitive operations that may or may not be used in combination. Two such operations are relevant for our analysis, viz. strengthening and mitigation, particularly used when adapting understatements (e.g. litotes) and overstatements (e.g. hyperbole) to their context of production.

In what follows we will apply this version of the Cognitive Linguistics approach to metaphor, metonymy and other cognitive operations to our data.

\section{ANALYSIS OF SOME INFORMAL SPEECH EXPRESSIONS}

\subsection{Happy is up/unhappy is down}

HAPPY IS UP is a metaphor in which a happy state is understood in terms of an upward position. On the contrary, UNHAPPY IS DOWN is a metaphor in which sadness is represented as a low position. This metaphor, put forward by Lakoff \& Johnson (1980: 15, 1999: 50) and further studied by Barcelona (1986) and Peña (1997), has an obvious experiential basis in the sense that when we are happy, energetic, etc. we are usually in an upright, elevated position: there is a correlation between the subjective judgement of happiness -an affective state-and the sensorimotor domain of bodily orientation or posture. In fact, when we are healthy we tend to be erect whereas if we are ill we are usually in bed since we need to rest in order to overcome the illness; besides, a logical consequence of being ill is unhappiness. Thus, this bodily experience constrains not only the input to the metaphorical mappings but also the nature of the mappings themselves.

In Spanish, the metaphor HAPPY IS UP/ SAD IS DOWN lies at the base of some informal expressions (which mainly belong to the domain of youth slang) like "subidón" and "bajón," which come from "subir" ("go up") and "bajar" ("go down"). Thus, it is not unusual to hear teenagers addressing their high-spirited peers with expressions like ¿Vas de subidón? (lit. "Are you in high spirits?”), ¿Qué tal el subidón? (lit. "How about your high emotional state?"). On the other hand, if their friends are in low-spirits, sad, etc. we usually hear expressions such as Estás de bajón (lit. "You're in low spirits"), Eres un bajapedos (lit. "You make my high spirits go down"), Te ha dado el bajón, Estás en baja forma, Estás bajo (lit. "You are low"). When someone is about to experience something good we can say Me lo sube (lit. "It cheers me up"), meaning that something is raising your spirits or cheering you up.

Finally, the metaphorical systems HAPPY IS UP/ SAD IS DOWN lie at the base of such English expressions as the following ones:

(1) I'm feeling up vs. I am really down.

(2) That boosted my spirits vs. The illness lowered my morale.

(3) My spirits rose vs. My spirits fell.

(4) You're in high spirits vs. You're in low spirits. 
(5) Thinking about her always gives me a lift vs. He's gone downhill in the last few months.

\subsection{Loss of self is loss of control. The absent subject metaphor}

According to Lakoff (1993: 9), it is normally expected that people will be able to control their actions. This expectation may fail for different reasons. For instance, one may be on drugs, one can be daydreaming, one may be mentally incompetent, crazy, euphoric, or overcome by passion.

The metaphorical model LOSS OF SELF IS LOSS OF CONTROL is used to conceptualise normal self-control by the Subject and the absence of it. This is a metaphor in which the Subject experiences normal self-control when it is in a normal location or (usually upright) position. In this respect, there are several normal locations for the Subject such as being on the earth, at home, on the ground, or at work, there are some others in which the normal location is in some bounded region (e.g. the whole body conceived of as an organic entity). In expressions such as Se te va la pinfla, or Se te va la cabeza (lit. "Your head is going away"), the head (which contains the Subject and is hence supposed to be in control of our whole body) moves from our body to some point which is not a normal location for it; consequently, there is lack of normal conscious self-control. Interestingly enough, this metaphorical movement of our head can be observed in two common gestures ${ }^{2}$ : first, the one in which our dominant hand moves towards the front while it rotates as if the head was moving and separating from the speaker's body and, second, the one in which the speaker usually touches or gets near the right hand side of his head with the thumb of his dominant hand while the rest of the fingers are together and extended and they generally move as if waving (see figure 3). Iconically, this gesture may symbolise a sort of wing which metaphorically stands for the fact that the head flies away. To end with, these gestures may not just accompany the aforementioned expressions but even some related instances linked to craziness such as "estás mal de la cabeza" ("you are out of your head"), "estás tarado," “estás loco" (“you are crazy”), etc.



Figure 3. A sign for stupid or fool.

\footnotetext{
2 According to Sweetser (1990), "gesture accompanying speech shows coherent and systematic metaphoric mappings."
} 
There are also many expressions in which we find a co-occurrence (in terms of Barcelona, 2002) of the aforementioned metaphor with an image-metaphor ${ }^{3}$ by which someone's head is replaced by an object with a similar form. This holds true of cases such as Se te va la bola (lit. "Your ball is going away"), Se te va la perola (lit. "Your pan is going away"), or Se te va la olla (lit. "Your cooker is going away"). These cases are examples of image-metaphors by means of which someone's head can be metaphorically conceived of as a ball, cooker, or pan because of its rounded form. In English, we can employ terms such as nut (as in "to go off one's nut"), loaf (as in Use your loaf, don't lose it!), coconut, pumpkin, etc.

\subsection{Knowledge is vision}

The KNOWING IS SEEING conceptual metaphor allows us to understand the abstract domain of knowledge by means of the concrete domain of sight. This is a metaphor with a clear experiential basis grounded in the fact that in early childhood human beings normally receive cognitive input by seeing (see Sweetser, 1990: 37-40). Nevertheless, whereas in the first years of one's life perception and cognition are conceived of as together (or conflated in terms of Johnson, 1997), due to the fact that there is a deep basic correlation between intellectual input and vision, afterwards these two domains separate from each other ("deconflation" in Johnson's words, 1997). This is the reason why we are able to use the metaphor KNOWING IS SEEING simply to indicate "awareness". Consider in this respect everyday language expressions like the following ones:

(6) I see what you're getting at.

(7) His claims aren't clear.

(8) The passage is opaque.

This metaphor is pervasive in youth expressions related to blindness. For example, imagine that one of your friends is so drunk that he can hardly control his actions. People would normally pass remarks about him such as Estás ciego (lit. "You're blind"), Vaya ciego que llevas (lit. "Nice blindness you carry along"), and Despierta (lit. "Wake up!"). It is typical to ask drunk people how many fingers we are showing them in order to check out their level of drunkenness. Obviously, the drunk person is able to see but his/her mind is unable to respond to the surrounding physical stimuli in a proper way. In this sense, despite the fact that we are using the action of "seeing" we are referring to the act of "perceiving" or "realising." In other words, we make use of words related to the physical domain of sight in order to refer to the abstract notion of awareness.

\subsection{Flirting is a game of chance}

When you are flirting with a girl or a boy, you cannot be sure about the final result, that is, if you will get her/him or not. This is usually a matter of the time you spend with a girl/

\footnotetext{
3 In an image-metaphor a mental image and its structure are mapped onto another mental image with its structure; thus, this type of metaphors are very rich in visual imagery, which makes them less usual in ordinary language and more typical of poetic or literary language.
} 
boy chatting or knowing each other. But, even though you spend much time trying to appear nice to her/his eyes, everything may fail in the end. Because of that, flirting with people can be conceived of as a game of chance in which you may get the final prize or lose it. Obviously, the greater the amount of money you spend the bigger the opportunities you have of winning the prize. Similarly, flirting with people can be seen in terms of games of chance in which meeting the person is starting to play, keeping the conversation is inserting coins and going on playing, getting the final prize is hooking up with the person, and losing it is being rejected by the person. This metaphor has proved to be pervasive in Spanish slang as attested by the following expressions:

(9) Le has estado metiendo fichas a Ana toda la noche. (Lit. "You've been inserting tokens in Ann all the night").

(10) ¿Has comprado fichas para María? (Lit. "Did you buy tokens for Mary?”).

(11) ¿Quieres más monedas para jugar? (Lit. "Do you want more coins to go on playing?").

(12) Eres un ludópata. Juegas a todo lo que tienes delante. (Lit."You are a compulsive gambler. You play all you have before you").

(13) Ya estás con el insert coin. (Lit. "You are already inserting coins").

(14) ¿Te ha tocado premio gordo?(Lit. "Did you win a big prize?").

As we can see, (9) is the typical expression that a person would say to a friend who has been flirting with a girl for the whole night, as if he had been playing the whole night. (10) is the question someone would ask a friend who seems to be interested in a girl. (11) would be the expression for someone who has already been talking to a girl and may be really interested in going on flirting with her. (12) is a funny expression which refers to a person who tries to flirt with every possible person he meets. (13) is an English expression that usually appears in arcades or games of chance; here it is a metaphor for trying to flirt with a girl/boy. Finally, (14) aims at checking out whether someone who has been flirting with a girl/boy - i.e. playing a game of chance_- has been compensated with kisses, sex or in any other related way.

\subsection{Love is war}

The LOVE IS WAR metaphor, first put forward by Lakoff \& Johnson (1980: 49), portrays love as if it were war. Some of the correspondences of this metaphor are: the lovers are the adversaries, one is usually the pursuer whereas the other tries to resist or fly away from the pursuer, the weapons used by the adversaries are usually someone's beauty, charm, manners, etc. As in any war, one of the adversaries may gradually give in to the other's actions until she/he finally surrenders to what the other wants. Finally, when there are no possibilities of winning the war, the attacker usually retreats.

In English, there are some expressions that exemplify this metaphor, for instance:

(15) He fled from her advances.

(16) She pursued him relentlessly.

(17) He is slowly gaining ground with her. 
(18) He made an ally of her mother.

(19) He is known for his many conquests.

(20) He won her hand in marriage.

In Spanish, the LOVE IS WAR metaphor is also very productive and we find expressions such as the following ones:

(21) Esta noche hay que asaltar a María. (Lit. "We should assail Mary tonight").

(22) Esta noche atacamos. (Lit. "We are going to attack tonight").

(23) La conquistó sin dificultades. (Lit. "He conquered her with no difficulty").

(24) Está cediendo a mis encantos. (Lit. "She is giving in to my charm").

(25) Se rindió/sucumbió a mis encantos. (Lit. "She surrendered to my charm").

(26) Me retiré a tiempo porque vi que no tenía nada que hacer con él. (Lit. "I retreated just in time as I saw I had no chances with him").

(27) Mario la perseguía sin tregua. (Lit. "Mario pursued her relentlessly").)

(28) Ganó la mano de la princesa en el combate (Lit. "He won the princess' hand in the fight").

(29) Se alió con su madre (Lit. "He allied himself with her mother").

As we can appreciate, (17), (21) and (22) portray the girl as if she were a sort of fortress the guy is going to attack. (23) is similar to (19) in that the conquered person can be considered the prize the conqueror wins, as attested in $(20)^{3}$ and $(28)^{4}$. (24) and (25) show that the courtship by one of the lovers makes the other increasingly give in and finally surrender. In (26) a girl is going to retreat and quit flirting because she realises there is no way she can get what she wants. (15), (16), and (27) portray love as if it were a pursuit. To end with, (18) and (29) show that in love relationships, as in war, we can also have allies.

\subsection{Being attractive is having physical force}

By means of this metaphor, put forward by Kövecses (1990: chapters 9 and 10), we think of sexual attraction in terms of explosive, electrical, chemical, or magnetic force. The origin of this metaphor is related to the fact that sexual attraction generates a strong physical response which includes the desire to draw as close as possible to the potential sexual partner. This response is comparable to the strong physical forces that are produced by engines, chemical reactions, etc.

Some linguistic realisations of BEING ATTRACTIVE IS HAVING PHYSICAL FOR$\mathrm{CE}$ are the following ones:

(30) Esa chica está como una moto. Es una Harley. (Lit. "That girl is like a motorbike. She's a Harley").

(31) Ese chaval está como un tren/locomotora. (Lit. "That guy is like train/engine").

(32) Menuda rubia explosiva. (Lit. "What an explosive blond!").

(33) Esta cañón. (Lit. "She is like a cannon").

(34) Menuda yegua tenemos delante. (Lit. "What a mare we have in front of us!").

\footnotetext{
3-4 Note the use of the metonymy HAND FOR PERSON (see Díez, 2000: 59-62).
} 
(35) Los polos opuestos se atraen (Lit. "Opposite poles attract").

(36) Hay mucha química entre nosotros. (Lit. "There is chemistry between us").

As we can see in the examples, in (30) and (31) we find two comparisons which are licensed by the metaphor under scrutiny; besides, the second sentence in (30) makes explicit use of the metaphor: all these instances employ means of transport which are rather characterised by having much power and force. (32) and (33) relate explosive force to gorgeous girls. (34) depicts a girl as if she were a sturdy mare, an animal particularly known for its pulling force and its ample proportions (as for the latter feature, the sentence can be explained on the basis of the PEOPLE ARE ANIMALS metaphor: a hefty mare maps onto a well-proportioned girl). (35) is based upon an example of magnetic force; magnetic force is a form of invisible attraction between physical entities and sexual attraction is also "invisible," which makes this notion readily amenable for this kind of metaphor. Finally, (36) is an instance of chemical force where "chemistry" is a metonymy of the target-insource kind whereby the science as a whole is taken to stand for one of its best-known experimental items: chemical reactions; as there are physical and emotional reactions in love, there are reactions in chemistry.

Interestingly enough, some of these examples depict the impact of sexual attraction as a physical explosion, which may lead to the metaphor SEXUAL IMPACT IS PHYSICAL EXPLOSION. For example, (30) shows the parallelism between a girl and a motorbike (which works by means of an engine in which there is an internal explosion); similarly, (31) depicts the similarity between a boy and a train/engine; in (33), cannons work by means of an internal explosion; and in (34), the force is pretty explicit. Furthermore, nowadays a well-established folk theory considers the heart a bomb which is usually related to one's feelings and desires. In this sense, we could also put forward the related metaphor SEXUAL IMPACT IS EXPLOSION OF ONE'S HEART. In fact, there are many expressions which exploit this metaphor such as Cada vez que la veo, mi corazón estalla (lit. "Everytime I see her my heart explodes"), Explota mi corazón (popular song; lit. "My heart explodes"), Mi corazón hace boom siempre que me cruzo con él (Lit. "Every time I meet him, my heart makes boom"), and others.

In English, there are also many expressions that exploit this metaphor, for example:

(37) She's devastating.

(38) I was knocked off my feet.

(39) I could feel the electricity between us.

(40) We were drawn to each other.

(41) He has a lot of animal magnetism.

As can be observed, (37), (38) and (40) depict attractiveness as a powerful and uncontrollable force we can experience. (41) makes use of magnetic force, as (35) above. Finally, (39) shows a sort of electric attraction between two people. 


\subsection{Love is magic}

Everyday language employs this metaphor, put forward by Lakoff \& Johnson (1980: 49), in multiple instances in which one of the lovers becomes the magician, the other being the one who experiences the magic. In Spanish, we find many expressions that employ this metaphor. Some of them are:

(42) Su belleza me hipnotizó. (Lit. "Her beauty hypnotised me").

(43) Me embrujó con sus encantos. (Lit. "He bewitched me with her charm").

(44) Me hechizó con sus palabras. (Lit. "He spelled me with her words").

(45) Lanzó un conjuro de amor sobre mí. (Lit. "She cast a love spell over me").

This metaphor is also very pervasive in English, with expressions such as:

(46) I do not remember the time when I was beginning to fall in love with her. But it is sure that, her beauty charmed me.

(47) She bewitched me with such a sweet and genial charm, I knew not when I wounded was, And when I found it, hugged the harm.

(48) I was impressed with her ability to laugh at herself and found myself becoming enchanted with her to a degree beyond her physical attractiveness.

(49) What is it about Daniel Niall that makes me so crazy? Has he spelled me to love him?

(50) When he hypnotised me, I didn't see much, just a pair of beautiful blue eyes, which were full of love.

The examples above show how we understand the domain of love in terms of magic. Note, however, that in English some terms are semantically restricted, such as * She sorcered $m e$, due to its negative connotation, while love usually implies a positive one. A possible experiential motivation for the metaphor under analysis may be based upon the fact that when we are in love, we just have eyes for that person, and hence we seem to be focusing only on him/her as if we had been enchanted and were not able to do any other thing. Also, if someone uses magic on you, you may just obey him/her, as a lover does with respect to the beloved.

\subsection{Love is fire}

The LOVE IS FIRE metaphor (Kövecses, 1990: 46) may stem from the primary one AFFECTION IS WARMTH, in which the subjective judgement of affection and the sensorimotor domain of temperature are paired. The primary experience that motivates the metaphor is based upon the fact that we usually feel warm when we are held affectionately. As for LOVE IS FIRE, this is even taken to a greater extent: love feelings and actions generally cause physical reactions in our body that lead to feel hot. That is the reason why there are many expressions which contain lexical items related to the domain of fire, namely, 
(51) Sus besos me hacían arder de pasión/me encendían. (Lit. "Her kisses made me burn of pasión/ lighted me up").

(52) Anoche estaba muy caliente. (Lit. "I was very hot yesterday").

(53) Nos dimos un calentón. (Lit. "We had a hot moment").

(54) Es una tía muy calentona. (Lit. "She is really hot").

(55) La chispa del amor saltó. (Lit. "The spark of love appeared").

In English, there are also many expressions containing this metaphor, which reveal its productivity:

(56) My heart's on fire.

(57) She is his latest flame.

(58) That kindled love in his heart.

(59) I don't want to get burned again.

(60) He was consumed by love.

(61) She is very hot.

Finally, with all this in mind, we can even posit the related metaphor KISSING (AND OTHER FORMS OF SEXUAL AROUSAL) IS SETTING ON FIRE. This metaphor is based upon LOVE IS FIRE, and underlies linguistic expressions such as (51) in the Spanish examples or the following ones in English,

(62) Your kisses make me burn like fire, and fill my heart full of desire.

(63) His passion-filled kiss lights me up; His love touches my soul, capturing my desire with each embrace.

Also, on the basis of the metaphor LIFE IS FIRE/ A FLAME, we may extend the previous metaphor to KISSING IS GIVING LIFE, which may be seen in both Spanish and English examples, namely:

(64) Sus besos me hacen resucitar (lit. "her kisses bring me back to life).

(65) Sus caricias me hacían sentirme vivo (lit. her caresses made me feel alive).

(66) (...) The way her voice tells me I matter... the way her kisses make me feel alive.

(67) His hug and kiss revive me.

(68) Then, warm, moist, perfect kisses revived me.

\subsection{Intimacy is physical closeness}

According to Lakoff \& Johnson (1999: 50), this is a primary metaphor in which we pair the subjective experience of intimacy and the sensorimotor experience of being physically close. Obviously, the primary experience upon which this metaphor is based is the fact that we are usually physically close to people we are intimate with. Moreover, when someone wants to be in more intimate terms with someone else, he usually tries to achieve to be physically closer to that person.

This metaphor is very productive in Spanish informal speech, leading to expressions such as, 
(69) María es una lapa, siempre está a mi lado. (Lit. "Mary is a limpet, she is always next to me").

(70) Juan es toda una garrapata. (Lit. "John is a whole tick").

(71) Menudo pulpo es. (Lit. "He is a real octopus!").

(72) Es un imán, o peor. (Lit. "He is a magnet, or worse").

(73) Hay que quitárselo de encima a todas horas. (Lit. "I have to be taking him off all the time").

Examples (69) and (70) are animal metaphors. Limpets and ticks characterise themselves by a strong adherence to a surface, which is normally the skin of a person or animal. Example (71) also contains an animal of this type but it includes sexual connotations: the metaphor here maps the long, flexible tentacles of the octopus and their ability to move quickly in an unpredictable way onto the arms and hands of the person who displays comparable quickness and unpredictability, sometimes trying to take advantage of someone else by touching his sexual organs. Example (72) makes use of magnetic force. In (73) someone is always so close to us that he seems to be a burden we are lifting or carrying, thus becoming a difficulty; in this sense, the primary metaphor DIFFICULTIES ARE BURDENS applies, which can be considered a co-ocurrence of two primary metaphors (in terms of Barcelona, 2002). We end up this section by commenting on an interesting expression that derives from (71), namely "más que brazos, John tiene tentáculos!" (Lit. "Rather than arms, John's got tentacles!"). This expression contains a target-in-source metonymy (i.e. "tentacles" standing for "long arms," since octopus are characterised for having extraordinary long tentacles which ultimately are their arms; thus "tentacles" map onto the subdomain of a person's arms). From the interactional point of view, we have a metonymic reduction of one of the correspondences of the metaphoric source.

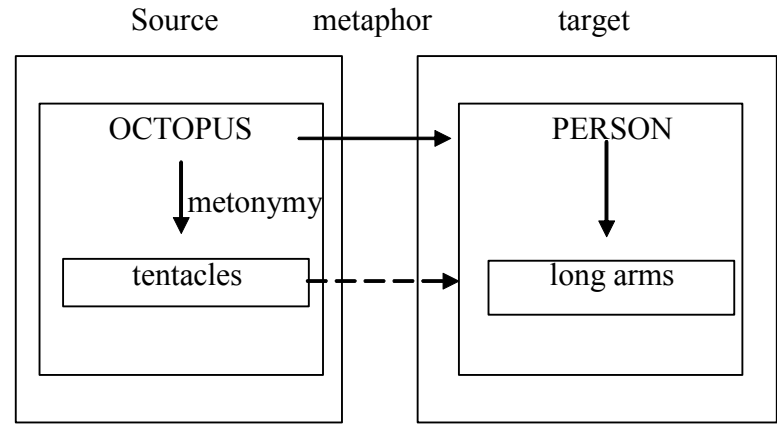

Figure 4. "Más que brazos, John tiene tentáculos!" (Lit. “Rather than arms, John’s got tentacles!"). 


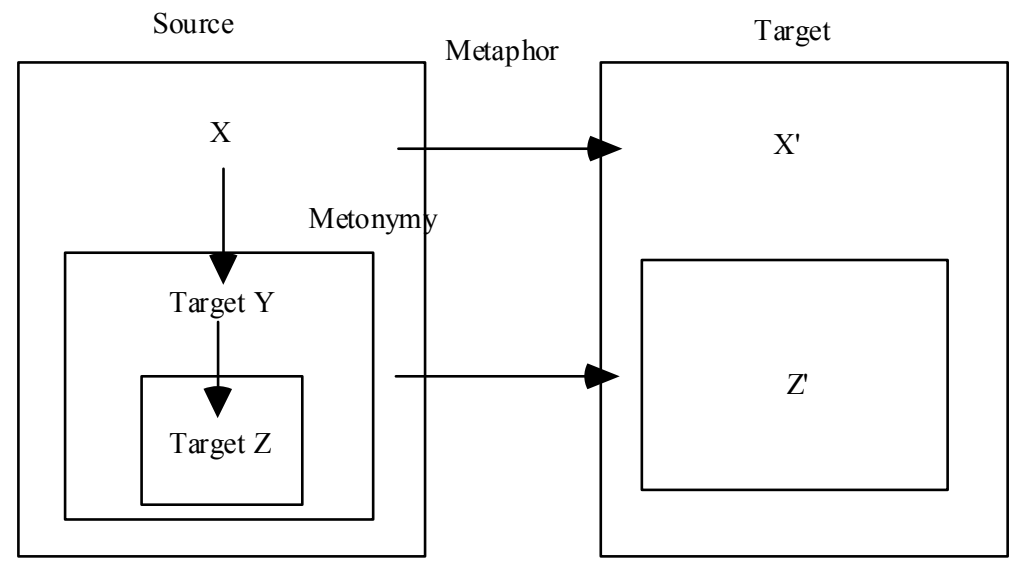

Figure 5. Metonymic reduction of one of the correspondences of the metaphoric source.

\subsection{Having sex is eating}

There are many instances in the religious world in which food stands for sex (e.g. an apple, as it was eaten by Eve in the biblical story). Furthermore, the act of eating in itself may be related to having sex. This metaphor has been labelled ACHIEVING A DESIRED OBJECT IS GETTING SOMETHING TO EAT or, rather, HAVING SEX IS EATING ${ }^{5}$, which may be observed in the following English examples,

(74) "I'm gonna taste her," Zan moved between her thighs, spreading them wider to get easier access to her dripping pussy.

(75) She is sexy, experience her. She is delicious, taste her.

(76) Who is the sweetest guy? I ate him yesterday.

This is a very productive metaphor which, according to Alarcón (2002), is characterised by the following correspondences:

\footnotetext{
${ }^{5}$ For a thorough analysis, see Alarcón (2002); available at http://www.udec.cl/ cognicio/comer.pdf
} 
EATING

HAVING SEX

\begin{tabular}{|l|l|}
\hline Stimuli leading to hunger & $\begin{array}{l}\text { Stimuli leading to sexual } \\
\text { desire }\end{array}$ \\
\hline Food & $\begin{array}{l}\text { Person who provokes sexual } \\
\text { desires }\end{array}$ \\
\hline $\begin{array}{l}\text { Effect caused by attractive } \\
\text { food }\end{array}$ & $\begin{array}{l}\text { Effect caused by a sexually } \\
\text { appealing person }\end{array}$ \\
\hline Desire to eat food & Sexual desire \\
\hline Decrease/increase of appetite & $\begin{array}{l}\text { Decrease/increase of sexual } \\
\text { desire }\end{array}$ \\
\hline Show desire to eat & Show desire to have sex \\
\hline Eating & Having sex \\
\hline Satisfactory state after eating & $\begin{array}{l}\text { Satisfactory state after having } \\
\text { sex }\end{array}$ \\
\hline Lack of appetite & Lack of sexual desire \\
\hline Eating another person's food & $\begin{array}{l}\text { Having sex with another } \\
\text { person's woman }\end{array}$ \\
\hline $\begin{array}{l}\text { Food that has never been } \\
\text { eaten. }\end{array}$ & $\begin{array}{l}\text { Person without sexual } \\
\text { relationships. }\end{array}$ \\
\hline $\begin{array}{l}\text { Eating without feeling } \\
\text { appetite }\end{array}$ & $\begin{array}{l}\text { Having sex without sexual } \\
\text { desire }\end{array}$ \\
\hline Dishes of a menu & Activities while having sex \\
\hline $\begin{array}{l}\text { First courses before the main } \\
\text { one }\end{array}$ & Sexual preparatory activities \\
\hline Non-seasoned food & $\begin{array}{l}\text { Non-passionate kisses and } \\
\text { caresses }\end{array}$ \\
\hline Eating without first courses & Having sex quickly \\
\hline Person who offers food. & Person who offers sex \\
\hline Food & Person who has had no sex \\
\hline food.
\end{tabular}

Figure 6. The EATING IS HAVING SEX metaphor.

In Spanish informal speech, we may find related expressions such as

(77) Se me hace la boca agua cada vez que te veo. (Lit. "Every time I see you my mouth is made water").

(78) Es un inapetente sexual. (Lit. "She has no sexual appetite").

(79) No he visto en mi vida mujer más apetecible. (Lit. "I haven’t seen in my life such an appetizing woman"). 
(80) Vamos a ver el ganado de este pueblo. (Lit. "Let us have a look at the cattle of this village").

(81) Mira esa chica. Es carne fresca/tierna. (Lit. "Look at that girl. She is fresh meat")").

(82) Está comiéndose una carne de primera. (Lit. "He is eating first-quality meat").

(83) Ella se dio cuenta y sin demora me dijo: yo también te comería. (Lit. "She realised and quickly said: I would eat you too").

(84) Devórame otra vez (popular song). (Lit. "Devour me again").

(85) Es una devora-hombres. (Lit. "She is a man-eater").

(86) Me comeré a Anita esta noche. (Lit. "I will eat Ann tonight").

(87) Tu amiga está para comérsela. (Lit. "Your friend is very appetising").

(88) Comer de la fruta del huerto ajeno. (Lit. "To eat fruit from someone else's orchard").

(89) Estoy muy mal. Hace ya un mes que no como. (Lit. "I'm really bad. It's been a month since I ate").

(90) Lo que pasa es que a éste nunca lo han catado. (Lit. "He hasn't been tasted").

(91) Yo creo que esa parte anatómica [pezones], que a muchos sólo les sirve como acompañamiento al plato de fondo, es una de las más grandes delicias del menú sexual. (Lit. "I think that one's nipples, which are just a secondary dish for many people, constitute one of the best delights of the sexual menu").

(92) En el matrimonio esos besos desaparecieron y dieron lugar a otros desabridos.

(Lit. "Kisses disappeared for the couple and new insipid things happened").

(93) Empezaremos por la almeja, pasaremos a los melones y acabaremos con las guindas del pastel. (Lit. "We shall start by the clam, then we will turn to the melons, and we will finish by the cherries of the cake").

(94) Estoy hambriento. (Lit. "I am hungry").

As we can observe, (77) shows that the effects caused by the vision of someone sexually attractive are comparable to those caused by the vision of appetising food. (78) compares the lack of sexual desire to the lack of appetite. (79) also establishes similarities between sexual desire and appetite. In (80) and (81) the person who provokes sexual desire is seen as food. (82)-(87) clearly portray the action of having sex as eating food-especially in the form of meat. In (88) eating another person's food is equivalent to having sex with another person's woman. (89) depicts the situation of a man who has not had sex as if he had not eaten for a long time. In (90) a person who has had no sexual relationships is seen as food that has never been eaten or even tasted. (91) and (92) depict the different sexual activities as if they were the different dishes of a menu. In (93) the sexual organs are seen as food, namely the clam is the clitoris, the melons are the woman's breasts, and the cherries are the nipples. To end with, in (94) the desire to have sex is seen in terms of hunger, i.e. the desire to eat food.

\subsection{Miscellany}

We end up this paper by reviewing a set of different expressions that deserve some commentary. Some expressions of informal speech are closely related to the world of

\footnotetext{
${ }^{6-7}$ Note that "meat" is a highly polysemous word in English. Amongst the several meanings of the term "meat," the $O E D$ quotes the one of "prostitute."
} 
drugs. In this domain, there are many metaphors in which the drug is replaced by something similar because of its form, colour, texture, etc. For example, chocolate can be replaced by hash, or tiza (i.e. chalk) for coke or speed. Interestingly enough, the case of marijuana is different as it is usually referred to as hierba (lit. "herb"), that is, the GENERIC FOR SPECIFIC metonymy applies in this case. The case of aspirina (aspirin) to refer to any kind of pill can be explained from two different perspectives: first, as a metaphor prompted by the resemblance in colour, size, shape, etc. between aspirins and other pills; second, as a case of the SPECIFIC FOR GENERIC metonymy, whereby a specific type of pill (i.e. aspirin) is used to refer to any kind of pill.

Speaking about the result of consuming drugs, we can find the metaphor BIG IS IMPORTANT and the metonymy CAUSE FOR RESULT. The former works in those cases in which people end words by the suffix -ón, which is usually telling of big size (e.g. fumón -to get a very big potehead, colocón -to get much stoned-, etc.). The latter applies to those cases in which the cause is mentioned to refer to the result, i.e. the final condition of the junkie (e.g. fumón, a certain physical and psychological condition which has been produced by smoking a lot).

Some metonymic uses should be also discussed. Imagine that someone is going to buy some heroin; in this case, he/she would ask for the product by means of the metonymy "TALEGO" FOR PRICE FOR PRODUCT (e.g. "dame tres talegos," "dame tres billetes," or even "dame tres verdes" (lit. "give me three pieces/notes/green ones") in which the metonymy is expanded into COLOUR OF NOTE FOR PRICE FOR PRODUCT.

Then, imagine that just when the drug dealers are doing business, the police appear. They can name the policemen by means of the colour of their uniforms. Let us study the COLOUR OF UNIFORM FOR POLICEMAN metonymy: if the local police appears they will be referred to as "los azules," ("the blue ones"); if they are the civil police they will be named "los verdes" ("the green ones"). Moreover, in the past, the national police were called "los grises" ("the grey ones"), because of the colour of their uniforms. There is also a funny expression to refer to the local police, the term "pitufos," ("smurfs") which may be explained on the basis of a metaphor originated on the similarity in colour -blue- between a smurf's body and a local police's uniform. Regarding the metonymy MATERIAL OF PART FOR CHARACTERISTIC PART FOR PERSON (in this case POLICEMAN), it is very common to call the police by the word "maderos" (lit. "the wooden ones") making reference to the material that was traditionally used in the prototypical sticks used by the police.

To end with, it is not just common, as we have seen, to name the security forces by their attributes or objects, but young people also apply similar metonymies to everyday people. If we meet a gorgeous blond crumpet in the street, many Spanish people would yell at her "Menuda rubia" (lit. "what a blond!) or "menudo morenazo" (lit. "what a black-haired!") if there is an attractive black-haired guy who is being observed by a group of girls; in these cases, the metonymy COLOUR OF HAIR FOR PERSON applies. It is common among the youth to refer to people by means of their sexual organs (PART -SEXUAL ORGAN-FOR PERSON), as in the expressions "vaya chochete que tenemos delante" (lit. "what a cunt we have in front of us") for females, or "menudo cimbrel" (lit. "what a dick!") for guys. 


\subsection{Theoretical implications}

Interestingly enough, many of these examples (especially those referring to sexual organs) can be considered cases of euphemism (cf. Chamizo \& Sánchez, 2000). We may thus stress the fact that metaphor does not only fulfil lexical creation and conceptual meaning derivation functions but, what is more, it may be ascribed roles related to the generation of emotional contextual effects. In other words, we can speak about, say, sexual organs by means of using their metaphoric counterparts instead of naming them explicitly, which may be impolite on certain occasions (cf. Chamizo Domínguez, 2004). In this sense, it is true that the Lakoffian view of metaphor disregards some other tropes such as irony, overstatement, understatement, euphemism and dysphemism, among others, but it provides us with relevant conceptual tools to explain them. In fact, cognitive operations related to contrast, reinforcement or strengthening, and mitigation (cf. Ruiz de Mendoza, 2005) are able to account for many cases of euphemism (i.e. an expression aimed by the speaker to be less offensive or disturbing to the listener than the word or phrase it substitutes) and dysphemism (i.e. the use of a harsh word or expression on purpose instead of a polite one), just as they are operational in cases of overstatement and understatement ${ }^{4}$ (cf. Herrero, forthcoming).

We can illustrate this point by means of the following examples of euphemism and dysphemism based upon "death." Let us take the neutral expression "he died," its euphemistic counterpart "he passed away," and its dysphemistic one "he is worm food." These instances can be interpreted on the basis of a scalar continuum based upon emotional and affective load. Whereas euphemisms are characterised by a light emotional load, dysphemisms are rather related to a heavy affective load; this is the case, for example, of many taboo words and insults (e.g. I am troubled > I am bad > I am fucked). These are the reasons why there are two basic cognitive operations at stake, namely, reinforcement and mitigation. In any case, we should bear in mind that the ultimate interpretative status of linguistic expressions is ultimately dependent on the context, as cogently argued by Chamizo Domínguez (2004).

As for the case of dysphemism, the encoder strengthens the emotional load of "He died" and uses the impolite expression "He is worm food," which stems from an underlying EFFECT FOR CAUSE metonymy (i.e. death causes a body to decay and become "worm wood").

\footnotetext{
${ }^{4}$ Whereas overstatement is characterised by a reinforcement operation on the part of the speaker (e.g. "This suitcase weighs too much for me" -say, 50 kilos- > This suitcase weighs a ton) and by a mitigation operation on the part of the listener (e.g. This suitcase weighs a ton > "This suitcase weighs a lot for a single person"), understatement is accomplished by a mitigation operation on the part of the speaker (e.g. $O h$, it's just a scratch -referring to a sizeable wound-) and by a reinforcement operation on the part of the hearer (e.g. It's just a scratch > "It's a sizeable wound").
} 


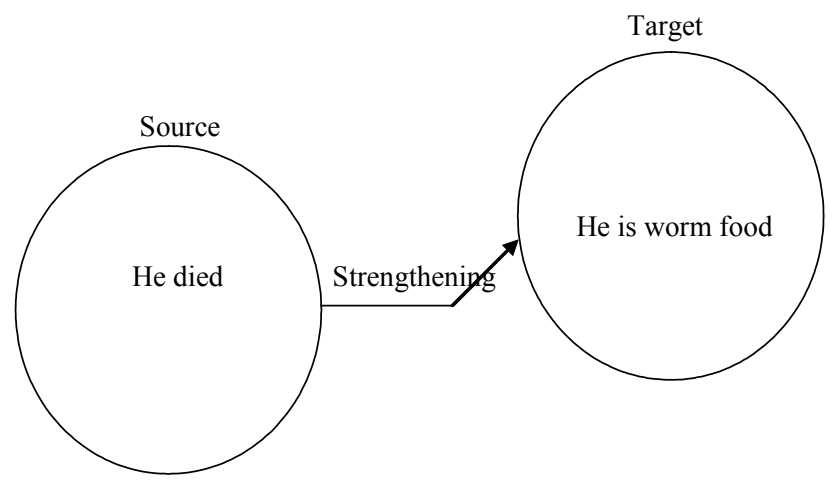

Figure. "He is worm food"

As regards euphemism, the speaker performs the converse operation, i.e. he mitigates and reduces the emotional and affective load of the neutral linguistic expression.

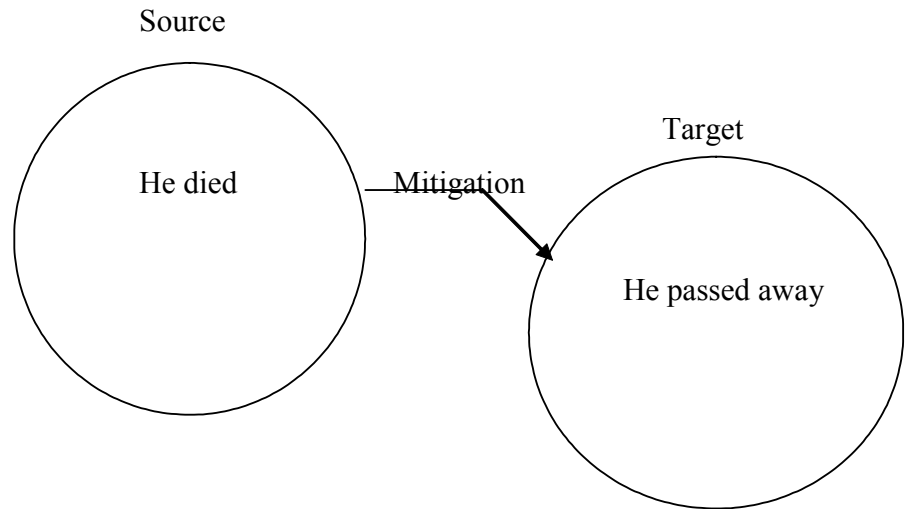

Figure. "He passed away"

\section{CONCLUSION}

In this paper, we have shown that conceptual metaphor and metonymy are essential tools that help us understand, and in fact condition, the basic meaning of the expressions of our language. Furthermore, these two cognitive operations have a strong linguistic impact, as may be gleaned from the domain of Spanish informal speech, which has supplied additional evidence in support of the thesis that metaphor and metonymy may be considered crucial mechanisms of lexical creation. In this connection, we have found evidence that metaphor can fulfil functions related to the generation of emotional contextual effects and act as a mechanism underlying some cases of euphemism. On top of that, we have identified two basic types of cognitive operations that motivate euphemism and dysphemism production, namely mitigation and strengthening. 
We have also been able to put forward the existence of metaphors not found in the literature such as SEXUAL IMPACT IS PHYSICAL EXPLOSION and FLIRTING IS A GAME OF CHANCE, and metonymies like COLOUR OF NOTE FOR PRICE FOR PRODUCT, COLOUR OF UNIFORM FOR POLICEMAN, COLOUR OF HAIR FOR PERSON, and PART (sexual organ) FOR PERSON.

Finally, the fact that many of the expressions analysed and their underlying metaphors have been shown to be similar in English and Spanish stresses the need to carry out a deeper intercultural study of these languages. Furthermore, with the addition of evidence from more languages, the fact that many of the metaphors studied in this proposal have a clearly experiential basis may point to the existence of some universal patterns of lexical creation which are deeply rooted in primary metaphors and metaphors based upon imageschemas.

\section{REFERENCES}

Barcelona, A. 1986. "On the Concept of Depression in American English: A Cognitive Approach." Revista Canaria de Estudios Ingleses 12: 7-35.

2002. "Clarifying and applying the notions of metaphor and metonymy within cognitive linguistics: An update." Metaphor and Metonymy in Comparison and Contrast. Eds. R. Dirven \& R. Pörings. Berlin/ New York: Mouton de Gruyter. 202-277.

Chamizo Domínguez, P. J. 2004. "La función social y cognitiva del eufemismo y del disfemismo." Panacea 5, 45-51.

Chamizo Domínguez P. J. \& F. SÁnchez Benedito. 2000. Lo que nunca se aprendió en clase: eufemismos y disfemismos en el lenguaje erótico inglés. Granada: Comares.

DAvidson, D. 1978. "What metaphors mean”. Critical Enquiry 5 (1), 31-47.

DíEz Velasco, O. 2000. "A cross-linguistic analysis of the nature of some hand metonymies in English and Spanish.” Atlantis, 2: XXII: 51-67.

DiRven, R. 1999. "Conversion as a conceptual metonymy of event schemata". Metonymy in Language and Thought. Eds. K. PANTHER \& G. RADDEN. Amsterdam \& Philadelphia: Benjamins.

Frath, P. 2003. "Metaphor, Polysemy and Usage.” Phraseological Units: Basic Concepts and their Application. Eds. David Allerton, Nadja Nesselhauf \& Paul SKANDERA. Basel: Schwabe.

2005. 'Why is there no ham in a hamburger?' A Study of Lexical Blends and Reanalysed Morphemisation.<http://u2.u-strasbg.fr/spiral/Equipe/Pierre/ Articles/HAM-NEW.doc>

Grice H. P. 1975. "Logic and Conversation." Syntax and Semantics, 3, Speech Acts. P. Cole \& J. L. Morgan. New York: Academic Press. 
Johnson, C. 1997. "Metaphor vs. Conflation in the Acquisition of Polysemy: The Case of SEE." Cultural, Typological and Psychological Issues in Cognitive Linguistics. Current issues in Linguistic Theory 152. Eds. M.K. HiRaga, C. Sinha, \& S.WILcox. Amsterdam: John Benjamins.

Косн, P. 2001. Metonymy. Unity in diversity. Journal of Historical Pragmatics 2.2. (201-244).

KöveCSES, Z. 1990. Emotion Concepts. New York: Springer-Verlag.

KöVECSES, Z. \& G. RADDEN. 1998. "Metonymy: developing a cognitive linguistic view". Cognitive Linguistics 9, 1: 37-77.

LAKOFF, G. 1993. "The contemporary theory of metaphor". Metaphor and Thought, $2^{\text {nd }}$. ed. Cambridge University Press. 202-251.

Lakoff, G, \& M. Turner 1989. More Than Cool Reason. A Field Guide to Poetic Metaphor. Chicago: The University of Chicago Press.

Lakoff, G. \& M. Johnson, 1980. Metaphors We Live By. Chicago \& London: The University of Chicago Press.

1999. Philosophy in the Flesh. The Embodied Mind and Its Challenge to Western Thought. New York: Basic Books.

Martinich, A. P. 1984. “A theory for metaphor”. Journal of Literary Semantics 13: 3556.

PeÑa, S. 1997. "The Role of the Event Structure Metaphor and of Image-Schematic Structure in Metaphors for Happiness and Sadness". Miscelánea 18, 253-266.

Ruiz de MENDOZa IBAÑEz, F.J. 1997a. "Metaphor, metonymy and conceptual Interaction”. Atlantis 19, 1:281-295.

1997b. "Cognitive and pragmatic aspects of metonymy". Cuadernos de Filología, 6.2: 161-178.

. 2000. "The role of mappings and domains in understanding metonymy". Metaphor and Metonymy at the Crossroads. A Cognitive Perspective. Ed. A. BARCELONA. Berlin, New York: Mouton de Gruyter. 109-132.

2005. "Linguistic interpretation and cognition." Cultural Matrix Reloaded. Romanian Society for English and American Studies. Seventh International Conference. Eds. E. Croitoru, D. Tuchel, \& M. Praisler. Bucarest: Didactica Si Pedagogica.

Ruiz de Mendoza Ibañez, F.J. \& L. Pérez Hernández. 2001. "Metonymy and the grammar: motivation, constraints and interaction". Language \& Communication 21-4: 321357.

Ruz de Mendoza IbáÑez, F. J. \& F. SantibáÑez SÁEnz. 2003. “Content and formal cognitive operations in construing meaning." Italian Journal of Linguistics 15(2): 293-320. 
Ruiz de Mendoza Ibañez, F.J. \& S. Peña Cervel. 2005. “Conceptual interaction, cognitive operations and projection spaces." Cognitive Linguistics: Internal Dynamics and Interdisciplinary Interaction. Eds. F. J. Ruiz de Mendoza IbáñEZ \& S. PeÑa Cervel. Berlin/New York: Mouton de Gruyter; forthcoming.

Searle, J. 1982. "Metaphor." Metaphor and Thought. Ed. A. Ortony. Cambridge: Cambridge University Press.

SWEETSER, E. 1998. Regular metaphoricity in gesture: bodily-based models of speech interaction. In Actes du $16^{e}$ Congrès International des Linguistes (CD-ROM). New York: Elsevier.

1990. From Etymology to Pragmatics. Cambridge: CUP. 